\title{
PENGARUH PERSENTASE GULA KELAPA DAN PERBANDINGAN TEPUNG KETAN DENGAN PISANG MULI TERHADAP MUTU DODOL YANG DIHASILKAN
}

\author{
Herliza, S.TP ${ }^{(1)}$ dan Retti Ninsix, S.TP., MP ${ }^{(2)}$ \\ ${ }^{(1)}$ Alumni Teknologi Pangan Faperta UNISI \\ ${ }^{(2)}$ Dosen Teknologi Pangan Faperta UNISI
}

\begin{abstract}
Abstrak
Penelitian ini bertujuan ntuk mengetahui pengaruh berbagai perbedaan Persentase gula kelapa dan perbandingan tepung ketan dan pisang muli terhadap dodol pisang. Hasil penelitian menunjukkan Hasil terbaik untuk kadar air diperoleh dari perlakuan T3S3 (campuran pisang muli 250 gram dan tepung ketan 750 gram ditambah gula kelapa 65\%) yaitu 22,93\%, kadar sukrosa terbaik diperoleh pada perlakuan T1S3 (campuran pisang muli 750 gram dan tepung ketan 250 gram ditambah gula kelapa 65\%) yaitu 58,43\%, dan nilai $\mathrm{pH}$ terendah diperoleh pada perlakuan T3S1 dan T3S2 yaitu 6,4. Perlakuan terbaik dari pengaruh persentasi gula kelapa dan perbandingan tepung ketan dengan pisang muli terhadap mutu dodol adalah perlakuan T1S3 (campuran pisang muli 750 gram, tepung ketan 250 gram, dan gula kelapa 65\%) dengan kadar air 26,83\%, kadar sukrosa 58,43\%, pH 6,53\%, uji organoleptik warna $3,90 \%$, aroma $3,30 \%$, rasa 3,80\%, dan tekstur 3,65\%. Dari penelitian disarankan perlu dilakukan penelitian lebih lanjut mengenai optimasi lama dan suhu pemasakan dodol, dan perlu adanya penelitian lebih lanjut dengan menggunakan bahan baku pengganti yang berbeda.
\end{abstract}

Kata Kunci : Pisang muli, dodol, tepung ketan

\section{PENDAHULUAN}

Produksi buah pisang di Indragiri Hilir dari tahun 2008 adalah 3122.93 ton dengan luas tanaman $578.38 \mathrm{Ha}$, tahun 2009 produksi buah pisang 2837,76 ton dengan luas tanaman 583,92 Ha, sedangkan untuk tahun 2010 produksi pisang adalah 3.373 ton (Dinas Pertanian Kab. Indragiri Hilir).

Pisang merupakan komoditas buah-buahan yang cepat mengalami kerusakan fisiologis, kimia, dan fisik. Akibatnya, dalam waktu singkat buah menjadi tidak segar lagi, sehingga mutunya akan menurun. Salah satu cara untuk mempertahan daya simpan buah pisang adalah dengan mengolahnya menjadi beberapa macam hasil olahan seperti dodol. Selain lebih tahan lama, pengolahan akan pisang menjadi bervariasi.

Penambahan gula dalam pembuatan dodol memiliki fungsi yang tidak terbatas pada pembentukan cita rasa manis, tetapi juga pada penyempurnaan cita rasa, warna, tekstur, dan kekentalan produk dodol. Gula juga berfungsi dalam pengawetan dodol, karena gula memiliki kelarutan yang tinggi, kemampuan mengurangi kelembaban relatif, daya ikat air.

Berdasarkan Penelitian Qinah (2010), bahwa jumlah tepung ketan yang ditambahkan di dalam pembuatan dodol adalah 250 gram , santan kelapa $500 \mathrm{ml}$, 
gula 800 gram dan menggunakan ubi jalar sebanyak 2000 gram. Setelah dilakukan penelitian tentang kadar gula pada dodol ubi jalar ungu dengan konsentrasi gula 800 gram dan tepung ketannya sebanyak 250 gram hasilnya didapatkan nilai rata-rata kadar gulanya $57,75 \%$.

Selama ini pisang muli hanya diolah menjadi buah meja yang bisa langsung dimakan tanpa diolah padahal pisang muli bisa diolah menjadi dodol. Dalam pembuatan dodol selama hanya tepung ketan, gula pasir, santan kelapa dan bahan tambahan lain seperti vanili.

Berdasarkan penelitian Steward (2009) penambahan gula aren 2000 gram, santan 2 liter, tepung ketan 700 gram, dan ampas nanas 400 gram dalam pembuatan dodol ampas nanas menghasilkan dodol ampas nanas dengan mutu terbaik. Permasalahan yang menjadi dasar dilakukan penelitian ini adalah berapa persen jumlah gula dan tepung ketan yang ditambahkan dalam pembuatan dodol pisang. Berdasarkan hal diatas penulis telah melakukan penelitian dengan judul "Pengaruh Persentasi Gula Kelapa dan Perbandingan Tepung Ketan Dengan Pisang Muli terhadap Mutu Dodol Pisang”.

\section{Tujuan Penelitian}

Tujuan penelitian ini adalah sebagai berikut :

1. Untuk mengetahui pengaruh berbagai perbedaan Persentase gula kelapa dan perbandingan tepung ketan dan pisang muli terhadap dodol pisang.

2. Untuk mendapatkan jumlah gula kelapa dan perbandingan tepung ketan dan pisang muli terbaik yang dapat ditambahkan dalam pembuatan dodol.

\section{Manfaat Penelitian}

Manfaat dari penelitian ini adalah sebagai berikut :

1. Memberikan informasi kepada masyarakat tentang pemanfaatan pisang yang dapat digunakan sebagai bahan dasar pembuatan dodol.

2. Dengan dihasikan dodol pisang diharapkan semakin banyak masyarakat yang mengkonsumsi dodol pisang sebagai sumber karbohidrat.

\section{METODE PENELITIAN}

\section{Bahan}

Bahan utama yang digunakan didalam penelitian ini adalah buah pisang uli atau muli. Buah pisang yang digunakan adalah buah pisang dari pasar Tembilahan, kabupaten Indragiri Hilir. Bahan lain yang digunakan adalah gula kelapa, santan, garam, tepung ketan,air, gula pasir, vanili, lerutan Luff Schoorl, larutan HCL $2 \mathrm{~N}$, Larutan KL $10 \%$, indikator amilum, $\mathrm{H}_{2} \mathrm{SO}_{4}$, dan air suling

\section{Alat}

Alat-alat yang digunakan didalam penelitian ini adalah pisau, timbangan, sendok pengaduk, kuali besar, kompor, gelas ukur, plastik, cawan petri, cawan aluminium, cawan proslen, Erlenmeyer, buret, neraca analitik, pipet tetes dan kertas saring.

\section{Metode Penelitian}

Penelitian ini menggunakan Rancangan Acak Lengkap ( RAL ) faktorial yang terdiri dari dua faktor yaitu Faktor (T) yaitu campuran pisang muli dengan tepung ketan, terdiri dari 3 taraf perlakuan yaitu :

T1 : campuran Pisang muli 750 gram dan tepung ketan 250 gram dengan perbandingan $3: 1$ 
T2 : campuran pisang muli 500 gram dan tepung ketan 500 gram degan perbandingan $2: 2$

T3 : campuran pisang muli 250 gram dan tepung ketan 750 gram dengan perbandingan $1: 3$

Faktor (S) yaitu persentase gula kelapa dengan 3 taraf perlakuan yaitu :

$\mathrm{S} 1: 45 \% / \mathrm{bb}$

$\mathrm{S} 2: 55 \% / \mathrm{bb}$

S3 : $65 \% / \mathrm{bb}$

Masing-masing perlakuan terdiri dari 3 (tiga) ulangan, sehingga diperoleh perlakuan adalah $(3 \times 3 \times 3)$ yaitu 27 perlakuan.

\section{Pelaksanaan Penelitian}

\section{Pembuatan Dodol Pisang}

Pembuatan dodol pisang hampir sama dengan pembuatan dodol buah pada umumnya dimana proses pembuatannya adalah sebagai berikut.

1. Pengsortiran

Pengsortiran pisang bertujuan untuk memisahkan buah pisang telah matang dengan yang masih mentah. Jumlah bahan baku pisang yang dipersiapkan sesui dengan perlakuan.

2. Pengupasan kulit

Pengupasan kulit pisang bertujuan untuk memisahkan kulit dengan daging pisang. Pengupasan kulit pisang dapat dilakukan dengan cara yang sederhana yaitu dengan menggunakakan pisau.

3. Pemotongan

Pemotangan daging buah pisang bertujuan untuk mempermudah proses penghancuran agar mendapatkan bubur yang bertekstur halus.

4. Penghalusan atau dijuicer

Penghalusan daging buah pisang dapat dilakukan dengan menggunakan blender yang dihancurkan hingga menjadi bubur.

5. Pencampuran (Perlakuan)

Buah pisang telah dihaluskan ditambahkan tepung ketan sesuai dengan perlakuan. Kemudian adononan dimasukkan kedalam larutan gula sesuai dengan perlakuan dan santan $500 \mathrm{ml}$ kemudian aduk secara merata.

6. Pemasakan

Adonan dimasak selama dua jam dengan suhu $80^{\circ} \mathrm{C}-90{ }^{0} \mathrm{C}$ sambil diaduk-aduk sampai kalis dan kental. Setelah adanan menjadi kalis Adonan dituangkan kedalam cetakan, agar dapat dipotong-potong dodol didinginkan terlebih dahulu sampai cukup keras. Setelah dodol dingin dilakukan pemotongan sesuai dengan yang dikehendaki. Kemudian dodol yang telah dipotong-potong dikemas didalam plastik.

\section{HASIL DAN PEMBAHASAN}

\section{Kadar Air}

Dari hasil analisis statistik yang dilakukan tentang interaksi pengaruh persentasi gula kelapa dan perbandingan tepung ketan dan pisang muli terhadap kadar air dodol pisang muli data disajikan pada tabel 1 .

Dari Tabel 1 dapat dilihat bahwa interaksi pengaruh persentasi gula kelapa dan perbandingan tepung ketan dengan pisang muli terhadap kadar air dodol pisang muli tidak memberikan pengaruh nyata terhadap dodol yang dihasilkan. Kadar air dodol pisang muli tertinggi adalah $27,26 \%$ yang diperoleh pada perlakuan T1S2 (campuran pisang muli 750 gram, tepung ketan 250 gram dan gula kelapa 55\%) sedangkan kadar air dodol pisang muli terendah diperoleh pada perlakuan T3S3 (campuran pisang 
muli 250 gram, tepung ketan 750 gram dan $65 \%$ ) yaitu $22,93 \%$. Hal ini diduga tingginya kadar air pada perlakuan T1S2 (campuran pisang muli 750 gram, tepung ketan 250 gram, dan gula kelapa 55\%) dikarenakan penambahan pisang muli yang tinggi 750 gram sedangkantepung ketan hanya 250 gram dan persentasi gula kelapa $55 \%$ sehingga gula kelapa dan tepung ketan tidak mampu mengikat kadar air yang terkandung pisang karena kadar air pada pisang cukup tinggi yaitu $62-75 \%$. tepung yang banyak dan persentasi gula kelapa yang tinggi.

Tabel 1. Interaksi Pengaruh Persentasi Gula Kelapa dan Perbandingan Tepung Ketan dengan Pisang Muli Terhadap Kadar Air Dodol Pisang Muli

\begin{tabular}{|c|c|}
\hline Perlakuan & Kadar Air (\%) \\
\hline $\begin{array}{l}\text { T1S2 (campuran pisang muli } 750 \text { gram, tepung ketan } 250 \text { gram } \\
\text { dan gula kelapa } 55 \% \text { ) }\end{array}$ & $27.26 \mathrm{a}$ \\
\hline $\begin{array}{l}\text { T1S1 (campuran pisang muli } 750 \text { gram, tepung ketan } 250 \text { gram } \\
\text { dan gula kelapa } 45 \% \text { ) }\end{array}$ & $26.99 \mathrm{a}$ \\
\hline $\begin{array}{l}\text { T1S3 (campuran pisang muli } 250 \text { gram, tepung ketan } 750 \text { gram } \\
\text { dan gula kelapa } 45 \% \text { ) }\end{array}$ & $26.83 \mathrm{a}$ \\
\hline $\begin{array}{l}\text { T2S2 ( campuran pisang muli } 500 \text { gram, tepung ketan } 500 \text { gram } \\
\text { dan gula kelapa 55\%) }\end{array}$ & $24.76 \mathrm{a}$ \\
\hline $\begin{array}{l}\text { T2S3 ( campuran pisang muli } 500 \text { gram, tepung ketan } 500 \text { gram } \\
\text { dan gula kelapa } 65 \% \text { ) }\end{array}$ & $24.74 \mathrm{a}$ \\
\hline $\begin{array}{l}\text { T3S2 (campuran pisang muli } 250 \text { gram, tepung ketan } 750 \text { gram } \\
\text { dan gula kelapa 55\%) }\end{array}$ & $24,60 \mathrm{a}$ \\
\hline $\begin{array}{l}\text { T2S1(campuran pisang muli } 500 \text { gram, tepung ketan } 500 \text { gram } \\
\text { dan gula kelapa } 45 \% \text { ) }\end{array}$ & $24,24 \mathrm{a}$ \\
\hline $\begin{array}{l}\text { T3S1 (campuran pisang muli } 250 \text { gram, tepung ketan } 750 \text { gram } \\
\text { dan gula kelapa } 45 \% \text { ) }\end{array}$ & $24,06 \mathrm{a}$ \\
\hline $\begin{array}{l}\text { T3S3 (campuran pisang muli } 250 \text { gram, tepung ketan } 750 \text { gram, } \\
\text { dan gula kelapa } 65 \% \text { ) }\end{array}$ & $22,93 \mathrm{a}$ \\
\hline
\end{tabular}

Keterangan: Angka-angka pada jalur atau kolom yang sama diikuti oleh huruf kecil yang sama berbeda tida nyata menurut uji lanjutTukey pada taraf nyata $5 \%$.

Menurut Buckle dkk, (1987) gula mempunyai kemampuan mengikat air yang ada didalam bahan pangan. Ikatan yang terjadi adalah ikatan hydrogen yang menyebabkan berkurangnya aktivitas air didalam bahan pangan. Kadar air pada dodol pisang muli pada tiap perlakuan ternyata belum memenuhi standar SNI dengan kadar air maksimum 20\%. Perlakuan T3S3( campuran pisang muli 250 gram, tepung ketan 750 gram dan gula kelapa 65\%) yaitu 22,93 adalah perlakuan yang kadar airnya hampir memenuhi standar SNI hal ini diduga tingginya persentase gula yang diberikan bila dibandingkan dengan persentase gula yang digunakan pada perlakuan lainnya.

\section{Kadar Sukrosa}

Dari hasil analisis statistik yang dilakukan tentang interaksi pengaruh persentasi gula kelapa dan perbandingan tepung ketan dengan pisang muli terhadap kadar sukrosa pada dodol pisang muli data disajikan pada Tabel 2 .

Pada Tabel 2 dapat dilihat bahwa interaksi pengaruh persentasi gula kelapa dan perbandingan tepung ketan dan pisang muli terhadap kadar sukrosa 
memberikan pengaruh berbeda nyata menurut BNJ pada taraf nyata $5 \%$ terhadap dodol pisang muli yang dihasikan. Kadar sukrosa tertinggi diperoleh pada perlakuan T1S2 (campuran pisang muli 750 gram, tepung ketan 250 gram dan gula kelapa 55\%) yaitu $57,43 \%$ dan kadar sukrosa terendah diperolah pada perlakuan T2S1 (campuran pisang muli 500 gram, tepung ketan 500 gram dan gula kelapa 45\%) yaitu $38,25 \%$. Perlakuan T2S1(campuran pisang muli 500, tepung ketan 500 gram dan gula kelapa 45\%) adalah perlakuan yang kadar sukrosanya tidak memenuhi standar SNI yaitu kadar sukrosa minimum $45 \%$. Hal ini diduga dikarenakan penambahan pisang tinggi yaitu 500 gram, tepung ketannya 500 gram dan persentasi gula $45 \%$. Hal inilah yang diduga rendahnya sukrosa pada perlakuan T2S1 (campuran pisang muli 500 gram, tepung ketan 500 gram, dan gula kelapa 45\%) disamping itu tinggnya penambahan pisang dan tepung ketan sementara persentase gula hanya $45 \%$.

Tabel 2. Interaksi Pengaruh Persentasi Gula Kelapa dan Perbandingan Tepung Ketan dengan Pisang Muli Terhadap Kadar Sukrosa Dodol Pisang Muli

\begin{tabular}{|c|c|}
\hline Perlakuan & $\begin{array}{c}\text { Kadar Sukrosa } \\
(\%)\end{array}$ \\
\hline $\begin{array}{l}\text { T1S3 (campuran pisang muli750 gram, tepung ketan } 250 \\
\text { gram dan gula kelapa } 65 \% \text { ) }\end{array}$ & $58.43 \mathrm{a}$ \\
\hline $\begin{array}{l}\text { T1S2 (campuran pisang muli } 750 \text { gram, tepung ketan } 250 \\
\text { gram dan gula kelapa } 55 \% \text { ) }\end{array}$ & $57.43 \mathrm{a}$ \\
\hline $\begin{array}{l}\text { T3S2 (campuran pisang muli } 250 \text { gram, tepung ketan } 750 \\
\text { gram dan gula kelapa } 45 \% \text { ) }\end{array}$ & $52.45 \mathrm{~b}$ \\
\hline $\begin{array}{l}\text { T2S3 ( campuran pisang muli } 500 \text { gram, tepung ketan } 500 \\
\text { gram dan gula kelapa } 65 \% \text { ) }\end{array}$ & $49.61 \mathrm{bc}$ \\
\hline $\begin{array}{l}\text { T1S1 ( campuran pisang muli } 750 \text { gram, tepung ketan } 250 \\
\text { gram dan gula kelapa } 45 \% \text { ) }\end{array}$ & $48.93 \mathrm{bcd}$ \\
\hline $\begin{array}{l}\text { T3S1 (campuran pisang muli } 250 \text { gram, tepung ketan } 750 \\
\text { gram dan gula kelapa } 45 \% \text { ) }\end{array}$ & 45.52 \\
\hline $\begin{array}{l}\text { T3S3(campuran pisang muli } 750 \text { gram, tepung ketan } 250 \\
\text { gram dan gula kelapa } 65 \% \text { ) }\end{array}$ & 44.67 \\
\hline $\begin{array}{l}\text { T2S2 (campuran pisang muli } 500 \text { gram, tepung ketan } 500 \\
\text { gram dan gula kelapa 55\%) }\end{array}$ & 44.48 \\
\hline $\begin{array}{l}\text { T2S1 (campuran pisang muli } 500 \text { gram, tepung ketan } 500 \\
\text { gram, dan gula kelapa } 45 \% \text { ) }\end{array}$ & 38.25 \\
\hline
\end{tabular}

Keterangan: Angka-angka pada jalur atau kolom yang sama diikuti oeh huruf kecil yang sama berbeda tida nyata menurut uji lanjut Tukey pada taraf $5 \%$.

Menurut Winarno (1997) dari beberapa monosakarida dan oligo sakarida gula atau sukrosa memliki tingkat kemanisan nomor dua setelah fluktosa yaitu sekitar 1,4 kali lebih manis dari gula. Selama proses pemanasan sebagian sukrosa atau gula terurai menjadi glukosa da fruktosa dan tidak dapat berbentuk beku karena kelarutan fruktosa dan glukosa sangat besar. Sifat ini menunjukkan semakin banyak gula yang ditambahkan jumlah sukrosa 
semakin besar dan rasa dodol semakin manis.

\section{Derajat Keasaman (pH)}

Dari hasil analisis statistik yang persentasi gula kelapa dan perbandingan tepung ketan dengan pisang muli terhadap $\mathrm{pH}$ dodol pisang muli. Hasil analisis dapat dilihat pada Tabel 3 . dilakukan tentang interaksi pengaruh

Tabel 3. Interaksi Pengaruh Persentasi Gula Kelapa dan Perbandingan Tepung Ketan dengan Pisang Muli Terhadap pH Dodol Pisang Muli

\begin{tabular}{|c|c|}
\hline Perlakuan & pH \\
\hline $\begin{array}{l}\text { T2S3 (campuran pisang muli } 500 \text { gram, tepung ketan } 500 \\
\text { gram dan gula kelapa } 65 \% \text { ) }\end{array}$ & $6.63 \mathrm{a}$ \\
\hline $\begin{array}{l}\text { T1S1 (campuran pisang muli } 750 \text { gram, tepung ketan } 250 \\
\text { gram dan gula kelapa } 45 \% \text { ) }\end{array}$ & $6.60 \mathrm{ab}$ \\
\hline $\begin{array}{l}\text { T2S2 (campuran pisang muli } 500 \text { gram, tepung ketan } 500 \\
\text { gram dan gula kelapa } 55 \% \text { ) }\end{array}$ & $6.60 \mathrm{ab}$ \\
\hline $\begin{array}{l}\text { T1S2 ( campuran pisang muli } 750 \text { gram, tepung ketan } 250 \\
\text { gram dan gula kelapa } 55 \% \text { ) }\end{array}$ & $6.53 \mathrm{ab}$ \\
\hline $\begin{array}{l}\text { T1S3 ( campuran pisang muli } 750 \text { gram, tepung ketan } 250 \\
\text { gram dan gula kelapa } 65 \% \text { ) }\end{array}$ & $6.53 \mathrm{ab}$ \\
\hline $\begin{array}{l}\text { T2S1 (campuran pisang muli } 500 \text { gram, tepung ketan } 500 \\
\text { gram dan gula kelapa } 45 \% \text { ) }\end{array}$ & $6.53 \mathrm{ab}$ \\
\hline $\begin{array}{l}\text { T3S3 (campuran pisang muli } 750 \text { gram, tepung ketan } 250 \\
\text { gram dan gula kelapa } 65 \% \text { ) }\end{array}$ & $6,50 \mathrm{ab}$ \\
\hline $\begin{array}{l}\text { T3S1 (campuran pisang muli } 250 \text { gram, tepung ketan } 750 \\
\text { gram dan gula kelapa } 45 \% \text { ) }\end{array}$ & $6,43 \mathrm{~b}$ \\
\hline $\begin{array}{l}\text { T3S2 (campuran pisang muli } 250 \text { gram, tepung ketan } 750 \\
\text { gram, dan gula kelapa 55\%) }\end{array}$ & $6,43 \mathrm{~b}$ \\
\hline
\end{tabular}

Keterangan: Angka-angka pada jalur atau kolom yang sama diikuti oeh huruf kecil yang sama berbeda tida nyata menurut uji lanjut Tukey pada nyata taraf $5 \%$.

Pada Tabel 3 dapat dilihat bahwa pengaruh persentasi gula kelapa dan perbandingan tepung ketan dengan pisang muli terhada $\mathrm{pH}$ memberikan pengaruh berbeda nyata menurut uji lanjut Tukey pada nyata taraf 5\% terhadap dodol pisang muli yang dihasilkan. $\mathrm{pH}$ tertinggi diperoleh pada perlakuan T2S3 (campuran pisang muli 500 gram, tepung ketan 500 gram dan gula kelapa 65\%) yaitu 6,63 dan $\mathrm{pH}$ terendah diperoleh pada perlakuan T3S2 (campuran pisang muli 250 gram, tepung ketan 750 dan gula kelapa 55\%) yaitu 6,43 . Kadar asam yang tinggi (pH rendah) diduga dikarenakan penambahan pisang yang bersifat asam yaitu vitamin C.

Menurut Buckle, dkk (1987) kadar gula yang tinggi bersamaan dengan kadar asam yang tinggi ( $\mathrm{pH}$ rendah) dapat menambah keawetan bahan pangan. Pada penelitian ini nilai $\mathrm{pH}$ dan kadar sukrosa berbada diduga pengaruh penambahan tepung ketan dan gula kelapa yang digunakan kurang bagus serta lama waktu pemasakan yang kurang.

\section{KESIMPULAN DAN SARAN}

\section{Kesimpulan}


Dari penelitian yang telah dilakukan, dapat disimpulkan :

1. Persentasi gula kelapa dan perbandingan tepung ketan dan pisang muli pada pembuatan dodol pisang tidak memberikan pengaruh nyata berpengaruh terhadap kadar air, ada memberikan pengaruh nyata terhadap kadar sukrosa, $\mathrm{pH}$, dan uji organoleptik yang meliputi warna, aroma, rasa, dan tekstur dodol pisang muli.

2. Hasil terbaik untuk kadar air diperoleh dari perlakuan T3S3 (campuran pisang muli 250 gram dan tepung ketan 750 gram ditambah gula kelapa 65\%) yaitu $22,93 \%$, kadar sukrosa terbaik diperoleh pada perlakuan T1S3 (campuran pisang muli 750 gram dan tepung ketan 250 gram ditambah gula kelapa 65\%) yaitu $58,43 \%$, dan nilai $\mathrm{pH}$ terendah diperoleh pada perlakuan T3S1 dan T3S2 yaitu 6,4.

3. Hasil terbaik untuk uji organoleptik yang meliputi warna terdapat pada perlakuan T2S3 ( campuran pisang muli 500 gram dan tepung ketan 500 gram ditambah gula kelapa $65 \%$ ) yaitu 3,95\%, aroma T2S3 (campuran pisang muli 500 gram dan tepung ketan 500 gram ditambah gula kelapa 65\%) yaitu $3,75 \%$, rasa diperoleh dari perlakuan T1S2 dan T1S3 yaitu 3,80\%, dan tektur diperoleh dari perlakuan T1S3 (campuran pisang muli 750 gram dan tepung ketan 250 gram ditambah gula kelapa 65\%) yaitu $3,65 \%$.

4. Perlakuan terbaik dari pengaruh persentasi gula kelapa dan perbandingan tepung ketan dengan pisang muli terhadap mutu dodol adalah perlakuan T1S3 (campuran pisang muli 750 gram, tepung ketan
250 gram, dan gula kelapa 65\%) dengan kadar air 26,83\%, kadar sukrosa 58,43\%, pH 6,53\%, uji organoleptik warna $3,90 \%$, aroma $3,30 \%$, rasa $3,80 \%$, dan tekstur $3,65 \%$.

\section{Saran}

Dari penelitian disarankan :

1. Dodol yang dihasilkan dalam penelitian ini masih belum memenuhi standar mutu dalam hal kadar air, oleh karena itu perlu dilakukan penelitian lebih lanjut mengenai optimasi lama dan suhu pemasakan dodol.

2. Perlu adanya penelitian lebih lanjut dengan menggunakan bahan baku pengganti yang berbeda.

\section{DAFTAR PUSTAKA}

Anonim. 2012. Resep Pembuatan Dodol Pisang.http://aspal putih.blogspot. com/2012/06/resep-dodolpisang.html

Apandi, Muchidin. Msc, Dr. 1984. Teknologi Buah dan Sayur. Penerbit Alumni, Bandung

Astawan dan Wahyuni, 1991. Teknologi Pengolahan Pangan Nabati Tepat Guna. Dalm Irawati, R,2001. Pembuatan Dodol Waluh (Kajian Penambahan Tepung Ketan dan Terigu Serta Gula Pasir) Tehadap Sifat Fisik, Kimia dan Organoleptik. Skripsi Fakulta Teknologi Pertanian. Universitas Brawijaya, Malang.

BPS. 2008. Indragri Hilir Dalam Angka.

Kantor Dinas Pertanian

Kabupaten Indragiri Hilir, Tembilahan.

BPS. 2009. Indragiri Hilir Dalam Angka.

Kantor Dinas Pertanian

Kabupaten Indragiri Hilir,

Tembilahan. 
Buckle K.A.R.A.Edwards. G.H Fleet dan M. Wootton. 1987. Ilmu Pangan. Terjemahan Purnomo H, dan Aidono, UI Press, Jakarta.

Haliza. 1992. Rancangan Proses Pembuatan Dodol Kweni. Fakultas Teknologi Pertanian IPB. Bogor.

Hartati, dkk. 1996. Pengembangan Teknologi Proses Pembuatan Dodol MakananTradisional Sulawesi Tengah. Departemen Perindustrian BPPI.

Hermana Rimwood, B. 1975. Coconut Palms Product. Their Processing In developing Countries, FAO, Roma.

Ismiatun. 1999. 20 Jenis Panganan dari Pisang. Trubus Agrisarana. Surabaya.

Kartika B., Pudji Hastuti dan Wahyu Saputro. 1998. Pedoman Uji Indrawi Bahan Panggan. Jakarta.

Kirana. 1981. Dodol pisang nangka. Bogor : Pusat Penelitian dan Pengembangan Teknologi Pangan.

Lubis. H.S.A. 2008. Uji RPM Alat Pengaduk Untuk Pembuatan Dodol. Fakultas Pertanian Universitas Sumatra Utara. Medan.

Rismundar. 2001. Bertanam Pisang. Sinar Baru Algesindo. Bandung.

Santoso, H. B. 1988. Teknologi Tepat Guna Pembuatan Gula Kelapa. Penerbit Kanisius. Yogyakarta. 65 hal.

Satuhu S. 1996. Penanganan dan Pengolahan Buah. Penebar Swadaya.
Satuhu, S., Supriayadi, A. 2003. Pisang Budidaya Pengolahan dan Prospek Pasar. Penebar Swadaya. Jakarta

SNI. Dodol. SNI 01-2986-1992. Pusat Standarisasi Industri. Departemen Perindustrian, Jakarta.

Soemaatmdja, D., 1992. Pengawetan Pangan di Indonesia IPB Bogor. Standar Nasional Indonesia. Bogor.

Sugiyono. 2002. Ilmu Pengetahuan Pangan. PAU Pangan Dan Gizi IPB. Bogor.

Steward, D. 2009. Penambahan Gula Aren Terhadap Mutu dan Daya Simpan Dodol Ampas Nenas ( Ananas comosusu L. Merr). Fakultas Pertanian UNDRI.

Suhardiyono, L., 1995. Tambahan Kelapa. Kanisius. Yogyakarta.

Sunarjono, H. 2002. Budidaya Pisang Dengan Bibit Kultur Jaringan. Penebar Swadaya. Jakarta.

Qinah, E. 2010. Pengaruh Konsentrasi Gula Pasir dan Tepung Ketan Terhadap Sifat Kimia, organoleptik Serta Daya Simpan Dodol Ubi Jalar Ungu. Fakultas Kesehatan Masyarakat Universitas Sumatra Utara.

Widya Damayanti, dkk 2000. Aneka Panganan. Surabaya: Trubus Agrisarana.

Winarno F.G. 1997. Kimia Pangan dan Kimia Gizi. PT. Gramedia. Pustaka Utama. Jakarta. 